\title{
Ergonomic theory and practice: What language learners do in a self-access room
}

Françoise Raby, Jacques Baille, Pascal Bressoux and Carol Chapelle

\section{CpenEdition}

Electronic version

URL: http://journals.openedition.org/asp/1175

DOI: $10.4000 /$ asp. 1175

ISBN: 978-2-8218-0394-7

ISSN: 2108-6354

Publisher

Groupe d'étude et de recherche en anglais de spécialité

Printed version

Date of publication: 1 November 2003

Number of pages: $67-84$

ISSN: 1246-8185

\section{Electronic reference}

Françoise Raby, Jacques Baille, Pascal Bressoux and Carol Chapelle, «Ergonomic theory and practice: What language learners do in a self-access room », ASp [Online], 41-42 | 2003, Online since 24 April 2010, connection on 30 April 2019. URL : http://journals.openedition.org/asp/1175; DOI : 10.4000/ asp. 1175

This text was automatically generated on 30 April 2019.

Tous droits réservés 


\title{
Ergonomic theory and practice: What language learners do in a self-access room
}

\author{
Françoise Raby, Jacques Baille, Pascal Bressoux and Carol Chapelle
}

\section{Introduction}

1 The aim of this paper is to present ergonomic theory and practise through a research program carried out in a language centre. ${ }^{1}$ Because the purpose of this paper is not just to present two empirical studies, but also to introduce the reader to educational cognitive ergonomics, the paper is organised as follows.

The first part describes the language centre in which the empirical studies took place, in particular the self-access room (SAR) and the guided autonomy (GA) system which was surveyed. The second part introduces the ergonomic theory with a particular emphasis on concepts relevant to the two empirical studies presented in the following part. In the third part, the ergonomic research procedure is illustrated by two empirical studies which began a longitudinal research program focused on the same language centre, and which lasted for seven years. The first two investigations were quantitative. The first one, a macroscopic study, aimed at describing the self-access room (SAR) of the language centre through patterns of behaviours. This exploratory investigation led to a second experimental study in which the authors sought to compare students' patterns of behaviour in two different modes. In the first one, students attended guided-autonomy classes (GA), therefore, their autonomous work was piloted by a tutor-teacher; in the second modality, students were coming out of their free will for a non-tutored form of work (NG).

3 Finally, the authors sum up the qualitative longitudinal research program which followed the two first studies. One part of the program was centred on the learning side 
(Raby \& Baillé 1997; Raby 2003); another part was focused on the teaching side (Collombet 1998; Borges \& Raby 2000; Borges 2001).

\section{The research setting: A self-access language learning room}

4 This research took place in the language-learning centre of a Social and Political Science University in France. In the university, students could study law, political science, economics, and social sciences and, in most cases, English for specialist classes (such as English for economists, lawyers or psychologists) was also provided. In those classes students essentially studied written English and had little opportunity to practise communicative English. In 1990, a language centre was set up to cater for the students' diverse pre-professional or cultural needs.

\subsection{The topological setting and equipment}

The language centre is an independent building with six language classrooms, two rooms equipped with a language laboratory and one self-access room (SAR), divided into two parts. One part is devoted to electronic equipments, with fifteen computers, eleven TV sets and twelve video recorders; in the second part of the room, the students can find all the available printed material, course-books and exercise-books, pedagogical guides, newspapers, periodicals, dictionaries and electronic resources, such as video cassettes, CD ROMs and disks.

\subsection{The pedagogical setting}

6 There are six permanent language teachers in the language centre, two English teachers, one German teacher, one Spanish teacher, one Italian teacher as well as about ten parttime teachers.

They have devised a pedagogical system which includes two main modes, languagepractise classes and guided-autonomy classes, but students may, equally, come freely for a non-assessed kind of work. Language-practise classes are centred on oral work, usually discussions about a video or printed document. Their work is controlled and rewarded by a credit system. Guided autonomy classes, which take place in the SAR, also enable students to get credits. They are like traditional classes in the sense that a teacher regularly meets a group of students and teachers call the roll and regularly control the students' work, but on the other hand, students individually work on their specific projects, using different media and the teacher acts as a "guide" not as a "pilot" (Benson \& Voller 1997; Chambers \& Davies 2001). Students may choose either to prepare for a foreign certification such as the TOEFL or the Sienna examinations; or to write a dissertation in a target language about a cultural subject of their choice. The pedagogical guide explains the goal of Guided autonomy classes which is to promote progress in autonomy and linguistic or cultural knowledge. Constraints are also made explicit, number of sessions, level to be reached, forms of control. Students are strongly encouraged to work collaboratively and to make use of the wealth of resources available. 
The brochure insists on the electronic equipment as a means to progress towards a greater autonomy.

Three times a year, the tutor-teacher has an individual interview in the target language with his/her tutees so as to know where they feel they stand in their project. It is the same type of interview for all five languages taught, and, in the end, students are given a mark.

9 Apart from the Guided autonomy classes which take place in the self-access room, students have to do twenty-three extra sessions on their own. This work extends the work initiated in class. They have to do twenty-three sessions of about fifty minutes each. Each time they come to the SAR, they are greeted by a member of the administrative staff who asks them to fill a grid in which they explain what resources they are going to use for what kind of work.

\section{Key notions in education ergonomics}

\subsection{Ergonomics}

Ergonomics comes from the Greek ergon, work, and nomos, law, rule. Ergonomics studies operators: men or women in their work-places. Everywhere, in firms, factories and in the educational world too, there are actors dealing with machines which are getting more and more sophisticated. Ergonomics is a unifying discipline which seeks to describe and interpret these men/machines interactions. To put things simply, there are two main schools of ergonomics, the American one and the European one. Although they may seem contradictory in their approach, they are, in fact complementary. The older one, by far the most influential, is the American school (the human factor school) which examines the general characteristics of men and women in order to find better ways of adapting machines or technical environments to these characteristics. The European school sees ergonomics as the analysis of the activity of operators carrying out tasks in the field. Generally speaking, the American school is preoccupied with designing the best possible instruments or programs. In this perspective, users are called upon to test these programs, but in laboratory conditions not in their ecological contexts. In the European perspective, on the other hand, ergonomists will be more interested in analyzing the dynamics of operators' activity in their normal setting. Nowadays, the tendency is to bring together the two trends, the human factors trend being more and more interested in the sphere of usage and the European school in the sphere of design (Montmollin 1996; Rabardel 1995; Caroll 1991). Only recently has ergonomics been applied to the study of teaching and learning a foreign language in specific work situations. ${ }^{2}$

\subsection{Educational ergonomics, a useful approach for CALL research}

11 Why adopt an ergonomic perspective in Computer Assisted Language Learning (CALL) research? The first reason lies in the fact that the preoccupation of the majority of language students, teachers or researchers is to improve work situations. The idea is not only to enable students to get more linguistic knowledge, but also to make the most of their learning resources, to become more autonomous and to derive some pleasure from language learning activities... (Raby to be published). Cognitive ergonomics, which seeks to pinpoint and analyse psychological factors involved in mental work, provides scientific 
knowledge and experimental procedures which help to better understand the language learning processes. with CALL data, that is to say with students learning foreign languages all over the world in all kinds of workplaces, will not easily lend themselves to generalisation, even if the greatest care has been given to statistical treatment. The reason for this, as Montmollin (1996) and Almaberti (1991) have stressed, is that the phenomena investigated are much too complex to be encompassed in a comprehensive and extended model. Yet, this does not mean that one should give up implementing methods that are coherent and structured, in other words open to contradiction and criticism.

\subsubsection{Behaviours and cognition}

Unlike many CALL studies which limit themselves to account for learners' representations or productions, ergonomics also takes into account their behaviours. In order to analyse a work situation, ergonomes or work analysts point out the relationships that unite behaviours and mental processes into a task model. If one lays the stress on the visible elements: behaviours, one will develop neo-behaviourist models; if one lays the stress on the invisible elements: mental activity, one will develop cognitivist models. The ergonomic procedure insists that there is no contradiction between the two kinds of models. It claims that, on the one hand, behaviours are the only concrete objects the researcher has a direct relation to, and, on the other hand, that mental activity cannot be reduced to behavioural patterns. Therefore, ergonomics as a discipline aims at developing complementary models within a unifying framework which takes into account behaviours and mental activity, physical behaviours and verbal behaviours, the actual performances or productions of the users and their representations (Sperandio 1984). To sum up, behaviours are a kind of gateway to cognitive processes insofar as they manifest, through motor and verbal phenomena, 
different kinds of procedures ranging from heuristic procedures to rules of usage (Montmollin 1984; Leplat 1997; Hoc 1992, 1996).

\subsubsection{Instrumental genesis, a cognitive ergonomic construct}

16 The first objects human beings are accustomed to manipulating are tools. A tool is a material object which is only an extension of an organ - a microphone is a tool, a piece of chalk as well. Later, young children begin to use instruments, more complex objects designed to be used for different tasks like a TV set or a computer (Leroi-Gourhan 1965; Simondon 1968; Dieuzède 1994). An instrument has two sides, a material side and a symbolical one. To use an instrument implies two different kinds of knowledge, a functional and a teleological one. The functional knowledge is the knowledge required to set something to work. In the case of a personal computer, for instance, there are now all sorts of functions shared by many programs, which, for the end-user, constitute a kind of "language" of the instrument. They are to be found in the different bars such as "files", "edition", "tools" etc. According to Rabardel, to learn this "language" is to appropriate the instrumentalisation of the instrument.

The second kind of knowledge is teleological, knowing how to get something to work for a specific purpose, what Rabardel calls the process of instrumentation (Rabardel 1995: $12,41,67)$. In the case of the present research, to master the process of instrumentation means to know how to use a personal computer, a TV set or a tape recorder, to carry out a specific language learning or teaching task. Thus, it becomes clear that, for cognitive ergonomists, an instrument is the combination of a material object and a subject's cognitive system, no instrument exists as long as a user has not started using it. In his book, Des outils pour des langues, Bertin (2002) suggests an approach which tends to unify a didactic and an ergonomic perspectives on behalf of CALL research. His work is situated in the sphere of design and his preoccupation is the right integration of different elements which interfere in a work situation in which the learner's activity is mediated both by the computer and a teacher. Borrowing from Rabardel and Vérillion's model of "Instrumented Activity Situations" (Rabardel \& Vérillion 1995), he elaborates a construct which also takes into account the language teacher and the target language:

\footnotetext{
Une approche ergonomique de la situation d'AMO (Apprentissage Médié par l'Ordinateur) intégrera nécessairement une réflexion sur les objectifs et contenus linguistiques de la formation (axe enseignant $\leftrightarrow$ langue), sur l'organisation de cette interaction linguistique dans l'ensemble de la formation (axe enseignant $\leftrightarrow$ apprenant), enfin sur le type d'interaction souhaitée entre la langue et l'apprenant et ses implications sur la relation entre la langue objet et la langue-cible (axe langue-apprenant). (Bertin 2002: 77)
}

In the same way and although their work is not situated in the ergonomic theoretical framework, a number of researchers who are at the same time teachers in French language centres ${ }^{4}$ also call for CALL or multimedia designs which take into account the potential users' characteristics and not just various potentialities of machines. For this purpose, it is necessary to examine the learners' interactions not just with an instrument (a computer or a textbook), but with the whole learning system devised by the teachers. Some French researchers will speak of the users' interactions with a "dispositif". In English, the closest concept to "dispositif" seems to be the notion of environment, yet the two concepts do not actually overlap as the word "dispositif" has a functional, pragmatic side which is not present in the more general concept of environment. 
19 A "dispositif" is the association of a material and a symbolical entity, just like an instrument, but it is larger in its scope. The learning environment, in this study, a SAR, included all the actors that interacted while working in it, teachers, students and the administrative staff. It comprised a technical apparatus, plus a pedagogical apparatus, plus an administrative one. It had didactic but also cultural and sociological features which became the subject of the following investigations carried out in a socioconstructivist - not just a cognitive - perspective (Wolton 1999; Raby 2003).

\subsubsection{Instrumental genesis}

20 There are two ways of looking at the usages of modern instruments in the language class. The first one belongs to the designer's sphere, it consists in conceiving all the different possible utilisations that you can make of an instrument, while the second one, anthropological, belongs to the users' sphere and consists in looking at what the actual users are doing with these instruments (Flichy 1995). The two approaches are necessary. First, because no efficient instrument could be designed that would not take into account the target-user from its conception; secondly, because if one wants to observe users, one needs to confront observations to model, and this model is partly provided by what the designers expect the end-users to do. To account for the way in which an individual appropriates or fails to appropriate a learning artefact, Rabardel and Vérillon have developed a theory of the instrument very much inspired by the activity theory of both Vytgosky (1978) and Leontiev (1981).

21 The term instrumental genesis refers to all the mental processes related to the specific strategies or rules implemented by learners as they are getting used to a new learning environment or a new instrument.

If cognition evolves, as genetic epistemology has shown, through interaction with the environment, then it can be expected, in the course of its genesis, to have accommodated to particular specific functional and structural features which characterise artefacts. Does this have an effect on cognitive development, on knowledge construction and processing, on the nature itself of the knowledge generated? If so, through what macro and microgenetic processes can this effect be thought to be actuated? (Rabardel \& Vérillon 1995 : 77)

23 Instrumental genesis implies that subjects are first users who, by repeating their uses, stabilise their good (or bad) strategies turning them into rules of usage. These strategies or rules are made visible through specific behaviours, looking, typing, pressing a button, speaking aloud... which can only be indirectly interpreted as behaviours of identification, completion, regulation or control of their task. These behaviours have been defined by Baillé and Raby (1997) and Raby (2003) as instrumental behaviours.

In this process, operators or teachers and learners are constantly re-defining their task, what they should do and in which conditions. Conditions include the choice of available media, the time constraints and the modes of help and control. This process goes on all along the working process depending on how successful operators are with their work. Leplat (1997) calls it redefinition of the task. In the end, there might be a big discrepancy between the expected or prescribed task designed by the teacher and the task redefined by the student. Yet, this discrepancy does not necessarily reveal a flaw in the didactic system; it may simply attest to the subjects' independence and autonomy. 


\section{An illustration of the ergonomic procedure, two empirical quantitative studies}

These two studies will serve to illustrate the ergonomic research procedure. Sometimes, ergonomists cannot rely on previous studies to build up hypotheses on which to base their research. In such cases, they start with observing the work situation and after a period of observation, which may be long and detailed, they possibly end up with some hypotheses. In this study, the pre-observations of the SAR had yielded a rather blurred image of the learning environment with a great variety of behaviours and, at the same time, what looked like repetitive patterns. Therefore, researchers have decided to use a construct which would generate a macroscopic image of the SAR seen as a work environment.

\subsection{The preliminary macroscopic study}

The SAR of this language centre was seen as a working space in which a variety of behaviours were displayed. These behaviours followed didactic/institutional constraints or the students' own goals and strategies.

\subsubsection{Participants}

The 116 students belonged to the same university and were characterised through four main variables, their field of study (e.g., Eco for economics, PoL for political science, soc for social sciences, LAW for law); the language they studied (e.g., GER for German, SPA for Spanish...), their year of study $\mathbf{Y 1}_{1}, \mathbf{Y} 2, \mathbf{Y} 3$, and their sex, (M for men and $\mathrm{w}$ for women).

Table 1. Subjects

\begin{tabular}{|l|l|l|l|}
\hline Academic speciality & Year of study & Language studied when observed & Sex \\
\hline \hline Law :LAW & Year $1: \mathbf{Y} 1$ & English : ENG & Men : M \\
\hline Economics : ECo & Year 2: Y2 & German : GER & Women : W \\
\hline Politics : POL & Year $3:$ Y3 & Italian : ITA & \\
\hline Social Sciences /SOC & & Spanish : SPA & \\
\hline
\end{tabular}

Each student was observed during fifty minutes and his/her moves, actions and spontaneous verbalisations in the course of action were noted down on a grid. The time devoted to each was also taken down. Data will be represented on the tables by codes (see table 1 and table 2) that will later appear in the maps issued from the statistical model we have been using (see figures $1 \& 2$ ). 


\subsubsection{Instrumental variables structured into categories of behavioural data}

Some students chose one medium and, then, stuck to it, others changed their medium during the work session, moving, for instance, from the printed medium to the computer. These data were ranged under the label: media selection

Other behaviours were related to the way in which learners controlled their tasks, altering sub-goals or procedures and resorting to different kinds of helps. Such behaviours were ranged under the label: regulating behaviours.

Finally, the time variable was also very relevant insofar as it influenced the management of the task. The amount of time spent by a learner in front of a medium was ranged under the label: work duration.

The Multiple Analysis Correspondence model demands that data should be coded in a dichotomic/exclusive way (see figure1 \& 2). Example: if the video was used, it will be noted video; if it was not used, it will be noted nvideo and the same will apply to all data. If a learner used a dictionary, it will be noted dic; if he did not, it will be noted ndic.

\section{Selection of the medium by the students}

33 There were four media: the computer (compu/ncompu), the video (video/nvideo), printed didactic documents $(d d / n d d)$, documents with a teaching/learning purpose), newspapers and periodicals (pap/npap).

\section{Regulating behaviours}

They are noted in the maps which describes these behaviours as inq if learners inquired before starting to work, and ninq if they got down to work immediately. In the same way, they might or not use a dictionary (dic/ndic) take notes (note/nnote) they were proceeding with the task in order to discover and memorise some vocabulary and expression. Sometimes, they had a break; sometimes, they never stopped working (pause/ npause). They either talked or not with their peers (com/ncom). Finally, some students asked for help either about the content of their task (helpc/nhelpc) or when they had a technical problem (helpt/nhelpt).

\section{Work duration}

Work duration is calculated by subtracting the total amount of interruptions (pause) from the total time spent in front of the medium. After a period of pre-observations, the work duration was split into four classes: $w d \mathbf{1}=$ less than 5 minutes; $w d 2$ is comprised between 5 and 10 minutes, $w d 3$ between 10 and 15 minutes and finally $w d 4=16$ minutes and more.

Table 2. Instrumental behaviours

\begin{tabular}{|l|l|l|l||l|l|}
\hline \multicolumn{2}{|c||}{} & \multicolumn{2}{c||}{ Regulating behaviours } & \multicolumn{2}{c|}{$\begin{array}{l}\text { Work duration in } \\
\text { mns }\end{array}$} \\
\hline Computer & $\begin{array}{l}\text { compu/ } \\
\text { ncompu }\end{array}$ & Preliminary inquiry & inq/ninq & $0<\mathrm{X}<5$ & wd1 \\
\hline Video & Vall/nvideo & Makes pauses & $\begin{array}{l}\text { pause/ } \\
\text { npause }\end{array}$ & $6<\mathrm{X}<10$ & wd2 \\
\hline
\end{tabular}




\begin{tabular}{|l|l|l|l|l|l|}
\hline $\begin{array}{l}\text { Didactic printed } \\
\text { documents }\end{array}$ & dd/ndd & Takes notes & note/nnote & X>10>15 & wd3 \\
\hline Papers & pap/npap & $\begin{array}{l}\text { Communicates with } \\
\text { peers }\end{array}$ & com/ncom & X=>16 & wd4 \\
\hline & $\begin{array}{l}\text { Seeks for content } \\
\text { help helpc/ } \\
\text { nhelpc }\end{array}$ & $\begin{array}{l}\text { helpm/ } \\
\text { nhelpm }\end{array}$ & \\
\hline & Seeks for material \\
& Uses a dictionary & dic/ndic & \\
\hline
\end{tabular}

\subsubsection{Data analysis}

defined as many characters in the space. Characterising this space consists in looking for proximities between these characters. The values taken by the discrete variables are called categories. Knowing that inertia measures the discriminating capacity between categories, the method consists in building a first axis whose inertia is maximum. Then, iteratively, the method creates a succession of orthogonal, two by two axes, with the same mode of a maximum inertia. At each step, the axes can be visualised through a correspondence map. A correspondence map displays two of the dimensions which emerge from principal components analysis of the distances between points (see pp13-14).

To interpret the maps, one proceeds in two stages, a first stage consists in elaborating an interpretation of the overall structure yielded by the axes; a second stage consists in studying the contribution of each category to the determination of each axis. The contribution of each factor is measured by a percentage of inertia. 
Figure 1. Axis one and two with projection of the supplementary variables pertaining to the subjects

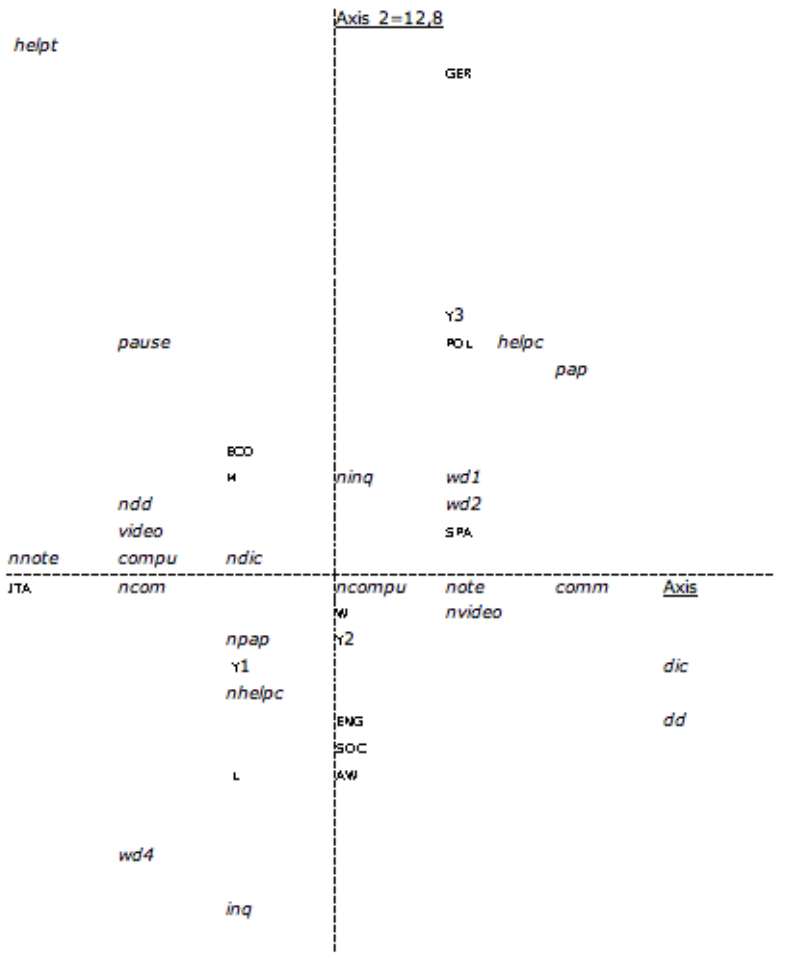

Y2, NHELPT and NPAUSE overlap so we have set their labelling aside 
Figure 2. Axis one and three with projection of the supplementary variables pertaining to the subjects

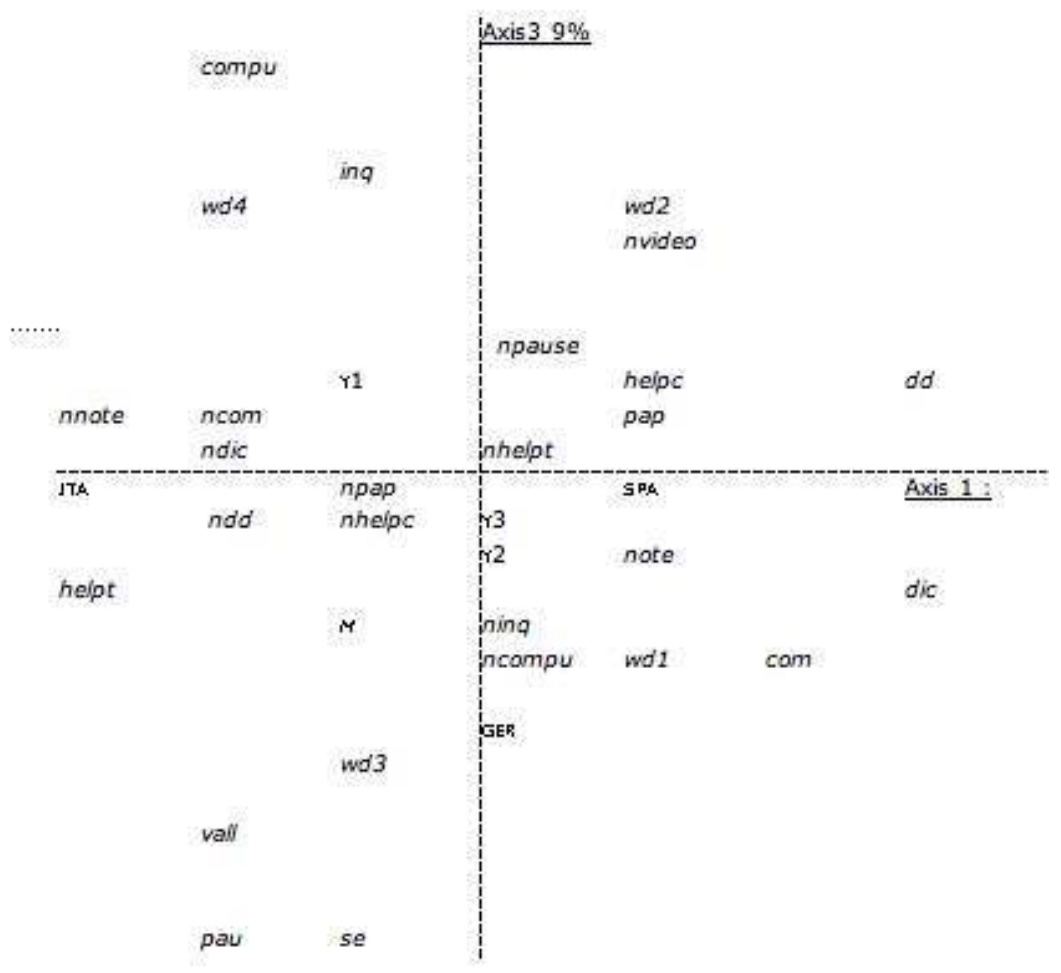

LAW, ENG and WORK DURATION overlap so we have set their labelling aside

\subsubsection{Main results}

\subsubsection{Weak contribution of the electronic media}

In figure 1 , axis 1 (horizontal) represents $19.9 \%$ of the total inertia. It is the main axis. From the point of view of media selection, it is the axis of didactic documents and papers (ddand pap) with $30 \%$ of the inertia, whereas from the point of view of instrumental behaviours, it can be defined as the axis of peer-communication (com), note-taking (note) and dictionary-use (dic). Axis 2 (vertical) represents $12.8 \%$ of the total inertia. It is predominantly the axis of instrumental behaviours: pause (12\%), help-seeking on content ( $h e l p c=12 \%)$, as well as technical problems (helpt $=25 \%)$ and preliminary inquiry (inq $=$ $0.08 \%)$.

The weak contribution of the electronic media to the determination of the first two axes was undoubtedly the most surprising finding of this research. It went against the expectations of the university ruling staff when they decided to create a highly equipped language centre and of the language centre's teachers who had devised a SAR highly based on the expected attraction and use of computers and TV sets. But the two maps also yield several interesting contrasts. 


\subsubsection{Contrasts in media use}

\section{did not ask for help, either technical or didactic, whereas those who did not inquire (ninq)} were those who later sought help (helpt and helpc). In map two, axis 3, one can notice a proximity between (compu) and (inq), which means that students who chose to work on the computer looked for information before setting down to work and then went on with their work with no further help-seeking. The opposition between preliminary research ( inq) and help-seeking (helpt and helpc) is confirmed.

\subsubsection{Introduction of the variables relating to the learners ${ }^{5}$}

In map one, the projection of supplementary variables did not allow strong inferences to be made, yet some conclusions may be tentatively elaborated in the light of the local context. Students who were studying economics seemed to resort to the electronic media and to show few instrumental behaviours. There was proximity between students that were studying politics (POL) and German (GER). They evinced the same characteristics as those in their third year (Y3), used predominantly newspapers or periodicals (pap) and sought help on content (helpc). On the other side of axis one, we found students that were studying social sciences (soc) and law (LAw), predominantly women. They seemed to work on didactic documents (dd) and not on electronic media (nvideo and ncompu). It followed that they did not ask for technical help (nhelpt) and did not need to have many breaks (npause). On each side of axis two, an opposition appeared between Spanish 
students (SPA) who took notes (note), communicated (com) and did not use electronic media, and Italian students (IтA) who used the electronic media (compu and video) and did not take notes (nnote) or communicate (ncom). As for the sex variable, one could notice that men and women were on opposite sides of the axes but their differentiation was really weak.

\subsection{The experimental study, behavioural dynamics and pedagogical guidance}

The first exploratory research had ignored the effect of the pedagogical context. In other words, no distinction had been made between students working in guided autonomy, that is to say those whose work was piloted and assessed by a tutor-teacher, and students whose work was not piloted and assessed. In the second investigation, researchers sought to know if the fact that students were guided made any difference in the way they behaved in the SAR. The pedagogical context was apprehended through two modes, guided autonomy students will be noted as (GA) and non-guided students will be noted as (NG). Incidentally, the MCA method had shown that the computer medium was clearly associated with the longest work duration ( $\mathrm{wd} 4=16$ minutes or more); therefore, it was decided to compare work durations with the computer to work durations with any other medium, in the two modes: GA and NG.

\subsubsection{Participants}

Four independent and equivalent groups were created taking into account the medium with which they had chosen to start working. Among GA students, ten had chosen the computer and ten other students had chosen another medium; the same applied to nonguided students, ten of them had chosen the computer while ten other students had chosen any other medium.

\subsubsection{Data collection and processing}

Each student was observed three times running while they were working on their own. In the SAR, there were some teacher-tutors or student-tutors, but they did not address students upon their arrival, they only responded to students who sought help. Observers had an observation grid in which they took down the number and the nature of media shifts from one session to another and within a single session.

We used the Analysis of Variance (ANOVA) statistical hypothesis testing procedure first developed by Fisher (1953) to analyse data generated by experimental designs.

The ANOVA makes it possible to know the influence of two independent variables (here the didactic contract and the medium) on a dependent variable (here the work duration). It is also able to point out possible interactions of these treatment effects on the single response variable (here the amount of time expressed in minutes). Here, the pedagogical variable (GA versus NG) is taken as the source of variation of the work duration in front of each medium (video or computer).

\subsubsection{Main results}


Table 3. Work durations measured in minutes

\begin{tabular}{|l|l|l|l|}
\hline & Computer & Others & Means \\
\hline GA & 68.3 & 81.5 & 74.9 \\
\hline NG & 94.12 & 57.4 & 75.8 \\
\hline Means & 81.2 & 69.5 & \\
\hline
\end{tabular}

Table 4. Main effects and interaction

\begin{tabular}{|l|l|l|l|l|l|l|}
\hline & df & Mean square & df & Mean square & & \\
\hline & Effect & Effect & Error & Error & F & Level $p$ \\
\hline Medium computer & 1 & 1392,40002 & 36 & 684,905579 & 2,032981 & 0,162533 \\
\hline $\begin{array}{l}\text { Pedagogical: } \\
\text { guided autonomy }\end{array}$ & 1 & 8,10000038 & 36 & 684,905579 & 0,011826 & 0,914005 \\
\hline \hline Interaction & 1 & 6250 & 36 & 684,905579 & 9,13 & $\mathbf{0 , 0 0 4 6 1 8}$ \\
\hline
\end{tabular}

51 One notices a real difference in work durations in front of the different media. The longest work duration in NG applies to the computer, whereas in AG the longest work duration applies to the other media. The ANOVA analysis points to a strong global interaction: $F=9.13 ; \mathrm{p} \leq .004$ for $3 \mathrm{df}$.

\subsection{Discussion}

Both studies accurately illustrate the concept of an exploratory research, that is to say a preliminary stage which aims at testing models and at formulating hypotheses for further research which can be more focused or more structured.

\subsubsection{Relevance of the macroscopic study}

53 Results of the first study can only be discussed in the light of the local context of this particular language centre where each language teacher brought his/her own conceptions and teaching strategies which in turn influenced the students' own working strategies. For instance, German students and Italian students were clearly opposed. The former worked on newspapers and did not choose the computer, while the latter were always associated with computer work. This is undoubtedly due to a specific trait of this particular language centre where there is only one Italian teacher and only one German teacher. In a further research the two teachers were interviewed about their work (Borges 2001). The Italian teacher had a long experience of CALL teaching, had received a specific training in computer science and believed very much in student autonomy. On the contrary, the German teacher was a newly trained teacher, had received little 
training in computer-assisted teaching and devoted her classes to the study of printed documents. She sent her students to the SAR mainly to learn more about Germany through the study of newspaper articles. She admitted to being rather suspicious of new educational technologies.

As far as the procedure is concerned, results have shown that Multiple Correspondence Analysis may be an interesting approach, not in terms of external validity, for results should be replicated in the same conditions and this is extremely difficult owing to the specificity of each CALL environment, but in terms of its internal validity, for the model seems to yield a relevant picture of a particular learning space and raises acute questions for the researcher.

\subsubsection{Relevance of chronometric and rhythmical studies for CALL research}

55 First, it is interesting to recall that Raby and Baillé (1997) had already found the same effect of the didactic guidance on rhythmical behaviours, students who were guided selected a greater variety of media and changed more often during their working sessions. In the present study, the chronometric and the rhythmical experiment also tend to show that the students who are guided build up a wider repertoire of behaviours and procedures. This is an illustration of an old tenet still current in scientific psychology which considers that temporal and rhythmical variations during the realisation of the task reveal variations in the procedural treatments and variations in the orientation of action (Sperandio 1980).

\subsubsection{Relevance of the theoretical framework and model}

Instrumentation and instrumentalisation

There are some results that no teacher or observer would have been able to predict. Such findings actually modify the vision we have formed of those learning environments and are not so easy to interpret. Among them, there is the weak part played by the electronic media compared to that played by the printed ones. Some would probably suggest that students are reluctant to use the computer or the video because there is always a risk that they might break down; others will argue that it is more comfortable to stick to an instrument which you are accustomed to and will put forward a piagetian interpretation in terms of schemes (Piaget 1967). Another interpretation can be proposed which is inspired by the very nature of the instruments themselves, by their functioning constraints. Printed documents are more easily transportable and one can quickly and easily move forward and backward in a book or a newspaper without fearing to lose some information. On the contrary, electronic equipments, essentially the video but also the computer, are not so easily manipulated. The recurrent opposition between instrumental behaviours linked to the printed media and the electronic media (preliminary inquiries, help-seeking, pauses, work durations) could be interpreted in the same way. It is necessary to insist on this question because, too often, CALL designers tend to focus too much on the pedagogical assets of their inventions ignoring difficulties of instrumentalisation. Being experts in both fields (computer design and language learning) they do not always anticipate the problems encountered by the end-users. As Raby and Baillé (1993) emphasised, the functioning problems (instrumentalisation) often check the process of instrumentation (using the instrument for a specific learning task). This is even truer when students are working on their own, without the mediation of a 
tutor who is able to help them to overcome these difficulties. The capacity to regulate one's task often linked to reflexive thinking is crucial to autonomous forms of work.

[...] ce qui importe n'est plus la quantité de connaissances sur la langue qu'a un apprenant, mais sa capacité de choisir parmi ses connaissances, d'utiliser ses stratégies cognitives et des procédures linguistiques afin d'effectuer des tâches diverses dans des situations de communication. (Walski 2002: 169) ${ }^{6}$

Relevance of the construct of instrumental genesis

The construct of instrumental genesis has been put forward to describe, analyse and interpret students' diverse behaviours. Although the didactic apparatus and the technical apparatus were the same for all students, behaviours were different. But a difference doesn't entail confusion, some patterns actually emerged in the Multiple Correspondence Maps since specific behaviours (pauses, communications, work durations etc.) were attached to specific media. This validates an anthropological construct of the instrument. In the case of this study, the reasons for the diversity of behaviours lay in the psychological diversity of the students, their knowledge of the SAR, their work conceptions, their knowledge of the foreign language, etc. In the same way, although it was impossible in the context of these observations to extract the mental processes of redefinition of the task, results also suggested that the process at work actually implied a process of task redefinition.

Therefore, results show the relevance of the descriptive model of a learning environment seen as a pattern of behaviours. Of course, behaviours only account for a small part of the system, but by combining these results with those derived from the research centred on teachers and on tutors, one can get an idea of how the actors of a self-access room manage or not to appropriate their learning environment.

\section{Summaries of the qualitative investigations that followed}

\subsection{The learning side}

60

Ergonomists do not limit themselves to behavioural data since what is important, for them, in fine, is to apprehend the mentalprocesses which lie behind these behaviours and which follow from the actors' knowledge and representations. The second stage of the program consisted of a qualitative study focused on six students working on a comprehension task. Using the cross-checking method devised by Raby (1996), three main kinds of data were cross-checked, the behaviours of students while realising the task, their conceptions obtained thanks to questionnaires, interviews or journals and, finally, traces of their activity, the notes they jotted down on their rough copies or their working sheets. Results showed that three cognitive models were emerging, epistemic, procedural and combined (Raby \& Baille 1997), and that students under-used the resources at their disposal and rarely asked for help (Raby 2003). Finally, the discourse analysis of their journals led the authors to qualify their first results. Indeed, contrary to what the behavioural patterns had suggested, the journals revealed that their greatest difficulties were not with the electronic equipment, or the innovating didactic system, but with the foreign language itself, an epistemic difficulty. At the same time, the journals showed that there was some confusion in the minds of students about their studentsinstructors (in French, their moniteurs) and their teacher-instructors. They did not seem 
to know very well what they should expect from these two kinds of tutors in guidedautonomy. For this reason, a further survey followed, focused on the teaching side of the language centre.

\subsection{The teaching side}

61 saw their tasks and pointed out that these tutor-students suffered from a lack of training for their new functions (Collombet 1998). Later, Borges and Raby (2000) and Borges (2001) studied the behaviours and conceptions developed by the teachers of the language centre. They compared the instrumental and didactic behaviours displayed by teachers when they were giving a traditional language practise class to the way they behaved when they were acting as instructors in the SAR. They found a lot of differences between teachers either in language practise classes or guided autonomy classes. They also found very different ways of appropriating the innovating working place, the SAR. One teacher, for instance, did not change at all and behaved exactly in the same way as when teaching in a language practise class, while another dramatically changed his actions, turning from leader to tutor; others seemed to hesitate between the two roles.

At each stage of the research, results were presented to the managing staff of the language centre and some adjustments and improvements were introduced in the wake of these discussions. Teachers wrote out some didactic leaflets intended for students who were not assisted by a tutor-teacher; they decided to spend less money on buying coursewares and more money on making didactic documents; they gave their student-tutors more pedagogical training; and, finally, they altogether changed the signal system in the SAR. In particular they made the student-tutor more visible by asking them to wear a little flag of their native country. These changes support the idea that empirical investigations in language centres actually make sense. However, it is not always very easy to work hand in hand with practitioners for a variety of reasons and it is often made easier when one researcher in the research team is at the same time a language teacher because he/she often, then, serves as a go-between.

\section{Conclusion}

The authors of this paper hope to have been able to suggest that ergonomics may serve as a unifying theoretical and methodological framework for CALL research seen as a crossdiscipline investigation, essentially because ergonomics makes it possible to integrate the three pillars on which CALL research is often based: cognitive and social psychology, second language acquisition and technology. Another asset of educational ergonomics is the variety of procedures it offers: qualitative and quantitative investigations, observations and experimentations, macroscopic and micro-genetic approaches. It is clear that educational cognitive ergonomists support those who fight the widespread and harmful idea according to which there would be an opposition between quantitative and qualitative studies. The question is not "quantitative" versus "qualitative" research, but rather to choose the right method corresponding to a specific problematics and to use the right scientific tools in order to avoid ad hoc conclusions. Moreover, researchers should refrain from generalising their results when they have not been using a method which entitles them to do so. 
64

Of course, the danger involved when applying ergonomics is that it often borrows from other disciplines such as semiotics, psycholinguistics, pragmatics or anthropology and there actually is a danger of syncretism (Chapelle \& al. 2003). But, once other disciplines, with their own models, knowledge and results, have found a unifying theoretical and methodological framework, such as a theory of the instrument or of a learning environment, for instance, the potential dangers of syncretism are avoidable. In the end, to go back to the debate launched by Chapelle and others in $\mathrm{LLT}^{7}$, the work we are carrying out as a team does not exclude other highly relevant and totally different approaches in their scopes, methods and in their theoretical foundations as well. L.L.T, Alsic or Asp offer numerous examples of the wide range of approaches in CALL research. We all agree that the role of research is not to provide technophiles or technophobes with ideological arguments about the pros and cons of CALL but to enable CALL actors to better understand their learning environments and transform them accordingly (Baillé \& Raby 1999; Baillé 2001). Therefore, it follows that researchers should be wary of comprehensive, holistic methods which do not lend themselves to any validation. This does not mean taking up a determinist, positivist view of scientific inquiry, just offering one's discourse to other researchers' testing and questioning. ${ }^{8}$

\section{BIBLIOGRAPHY}

Almaberti, R. et al. 1991. Modèles en analyse du travail. Liège: Mardaga.

Baillé, J. 1997. “Modélisation et expérimentation en ergonomie cognitive de la formation”. In Hadji C. \& J. Baillé (eds.), Recherche et éducation: vers une nouvelle alliance. Brussels: De Boeck Université, 191-221.

Baillé, J. 2001. « Mirage pédagogique et réalité instrumentale en multimédia éducatif. » in Actes du dixième colloque international de L'AFIRSE : Technologies en éducation : études et recherches, Albano Estrela \& Jorge Ferreira (Eds), 4-45. Lisbon: Edition de l'Université.

Baillé, J. \& F. Raby. 1999. “Machineries sémiotiques et médiations techniques. Remarques introductives”. InAgostinelli S. (ed.), Comment penser la communication des connaissances du CD rom à l'Internet. Paris: L'Harmattan, 159-193.

Benson, P. \& P. Voller. 1997. Autonomy and Independence in Language Learning. London and New York: Longman.

Benzecri, J. P. 1973. L'analyse des données. L'analyse des correspondances. Paris: Dunod.

Benzecri, J. P. 1980. L'analyse des données, tome 2. Paris: Bordas.

Benzecri, J. P. 1992. Correspondence Analysis Handbook. New York: Dekker.

Bertin, J.-C. 1994. “Conception de leçons multimédia : liberté ou guidage ?”. ASp 19-22, 313-331.

Bertin J.-C. 2002. Des outils pour des langues. Paris: Ellipses. 
Borges, M. 2001. Les usages des technologies de l'information et de la communication par des enseignants dans un dispositif de formation tutorée en langues vivantes étrangères. Unpublished Dissertation. Université Pierre Mendès France de Grenoble.

Borges, M. \& F. Raby. 2000. “Un exemple d'une démarche ergonomique appliquée à l'usage des TICE dans l'enseignement des langues étrangères”. In Albano Estrela \& J. Ferreira (eds.), Actes du dixième colloque international de L'AFIRSE : Technologies en éducation, études et recherches, 269-289. Lisbon : Edition de l'Université.

Caroll, J.M. 1991. “Introduction: The Kittle House Manifesto". In Caroll J. M. (ed.), Designing Interaction. Psychology and the Interface. New York: Cambridge University Press, 1-16.

Cazade, A. 1999a. "De l'usage des courbes sonores et autres supports graphiques pour aider l'apprenant en langues”. Alsic 2/2, 3-32. <http://alsic.univ-fcomte.fr>

Cazade, A. 1999b. "Une pédagogie multimédia, sinon rien? Outils pédagogiques et pédagogie de l'outil”. Les Cahiers du Lairdil. Décembre.

Cazade, A. 2000. "De l'expérimentation du multimédia à l'analyse, quelques pistes pour tirer parti d'un parcours d'apprenant en langues". ASp 23-26, 441-462.

Chambers A. \& G. Davies (eds). 2001. ICT and Language Learning: a European perspective. Lisse: Swets and Zeitlinger.

Chapelle, C. 1997. “CALL in the year 2000: Still in search of research agendas?”. Language Learning and Technology 1/1, 19-43.

Chapelle, C. 1999. "Research questions for a CALL research agenda: A reply to Rafael Salaberry". Language Learning and Technology 3/1, 108-113.

Chapelle, C. 2001. Computer applications in second language acquisition: Foundations for teaching, testing, and research. Cambridge: Cambridge University Press.

Chapelle, C. \& J. Jamieson. 1989. “Research trends in computer-assisted language learning”. In Pennington M. (ed.), Teaching language with computers: The state of the art. San Francisco : Athelstan Publishing,47-59.

Chapelle, C., L. Luo \& F. Raby. 2003. "Three analytic perspectives for analysis of process data in CALL environments". Paper presented at the 2003 World Call conference. Caligari.

Colombet, R. 1998. "Le monitorat dans un centre ressource de langues". Les Cahiers de l'APLIUT $18 / 2,12-28$.

Dieuzède, H. 1994. Les nouvelles technologies, outils d'enseignement. Paris: Nathan.

Fisher, R. 1953. “The logic of inductive inference”. Journal Royal Statistical Society, Series A 98, 39-54.

Flichy, P. 1995. L'innovation technique. Récents développements en sciences sociales. Vers une nouvelle théorie de l'innovation. Paris: La Découverte.

Hegelheimer, V. \& C. Chapelle. 2000. "Methodological issues in research on learner-computer interactions with CALL". Language Learning and Technology 4/1, 41-59

Hoc, J.-M. 1992. Psychologie cognitive de la planification. Grenoble: Presses Universitaire de Grenoble.

Hoc, J.-M. 1996. Supervision et contrôle de processus. La cognition en situation dynamique. Grenoble: Presses Universitaire de Grenoble.

Leplat, J. 1997. Regards sur l'activité en situation de travail. Paris: Presses Universitaires de France. 
Leroi-Gourhan, A. Le geste et la parole. La mémoire et les rythmes. Paris: Albin Michel.

De Montmollin, M. 1984. L'intelligence de la tâche. Berne: Peter Lang.

De Montmollin, M. 1996. L'ergonomie. Paris: La découverte.

Leontiev, A. 1981. Problems of the development of the mind. Moscow: Édition du progrès.

Percebois, J. 2002. “Contribution de l'enseignant d'anglais de spécialité à la conscientisation des stratégies d'apprentissage”. ASp 37-38, 141-153.

Piaget, J. 1967. La psychologie de l'intelligence. Paris: Armand Colin.

Rabardel, P. 1995. Les hommes et les technologies. Approche cognitive des instruments contemporains. Paris: Armand Colin.

Rabardel, P. \& P. Vérillon. 1995. “Cognition and Artefacts: A Contribution to the Study of Thought in Relation to Instrumented Activity”. European Journal of Psychology of Education 10/1, 77-101.

Raby, F. 1996. Apprentissage de l'anglais et nouvelles technologies éducatives: contribution de l'ergonomie cognitive à la didactique des langues. Unpublished PhD Dissertation. Département des langues vivantes pratiques. Université de Bordeaux 2.604p.

Raby, F. 2003. "Exemples d'une méthodologie de recherche de type ergonomique dans le domaine des TICE et des langues étrangères : des comportements vers les strategies". Les Cahiers du Lairdil $12,33-50$.

Raby, F. To be published (a). “A Cognitive Ergonomic Approach to CALL research”. In Egbert J. \& G. Petrie (eds.), CALL Research Perspectives. Mahwah NJ: Lawrence Erlbaum Associates Publishers.

Raby, F. To be published (b). User-Centred Researches on CALL. An Ergonomic Perspective. Lisse: Zwets \& Zeitlinger.

Raby, F. \& J. Baillé. 1993. “A Few Cognitive Issues in Multimedia Language Teaching” Bickerton D. (ed.), New Technologies, ASp 4, 17-32.

Raby, F. \& J. Baillé. 1997. "L'approche ergonomique des stratégies d'apprentissage dans l'apprentissage institutionnel d'une langue étrangère". Les cahiers de l'APLIUT 16/3, 10-21.

Raby, F. \& P. Dessus. 1999. "L'ergonomie cognitive comme outil de recherche appliquée à la formation des enseignants d'anglais". In Triquet, E. \& C. Fabre-Col (eds.), De la recherche aux modèles et outils opératoires en formation. Quels liens? Quelles interactions? Grenoble: IUFM de Grenoble.

Rasmussen, J. 1993. "Analysis of tasks, activities and work in the field and in laboratories". Le travail humain 2-3, 133-156.

Simondon, G. 1965. Du mode d'existence des objets techniques. Paris: Aubier.

Sperandio, J. C. 1980. La psychologie en ergonomie. Paris: Presses Universitaires de France.

Sperandio, J. C. 1984. L'ergonomie du travail mental. Paris: Masson.

Toma, A. 1997. L'enseignant face au multimédia. Paris: Pédagogie Internationale.

Toma, A. 1999. "Fonctions didactiques et architectures d'un laboratoire de langues de type logiciel”. Les Cahiers du Lairdil, Décembre.

Toma, A. 2003. "La didactique du multimédia en langues". Paper presented at the Atelier de didactique. SAES Grenoble.

Vytgotsky, LS. 1978. Mind in society. Cambridge: MIT. 
Walski, J. 2002. "Va et fais de même : de l'autonomie guidée vers une utilisation autonome de la langue”. ASp 37-38, 167-172.

Wolton, D. (ed.). 1999. Le dispositif, entre usage et concept. Paris: Hermès CNRS Éditions.

\section{NOTES}

1. The research produced quite a few publications which will all be cited in the course of this paper. We do apologise for the fact that our names will, consequently, often be quoted. This is by no means due to a hypertrophy of a kind of collective ego, but only to the fact that it is the sum of these publications that makes the whole research program.

2. Cf. Raby 1996, Raby 2003; Raby \& Dessus, 1999; Raby \& Baillé 1993, 1997, 1999; Baillé 1997, 2000; Rézeau 2002; Bertin 1994, 2002.

3. The research team was initiated by Jacques Baillé, in an educational science laboratory, under the name of DEACT (Didactique Expérimentale et Appropriation des Connaissances Techniques). It now works under the supervision of Erica De Vries and has changed its name for COTEFOR, " Connaissances et Technologies pour la Formation". It includes cognitive psychologists, specialists in instructional design and educational sciences but also specialists from different academic disciplines such as second language learning, first language learning, physics, maths and French. $<$ www.upmf-grenoble.fr/sciedu/>.

4. Cf. Cazade 1999a \& 1999b, 2000; Toma 1997, 1999a \& b, 2003; Rézeau 2002; Bertin 2002.

5. Let us recall that GER or ITA do not mean German or Italian students, but students who are studying Italian or German.

6. Also, cf., in the same issue of ASp about learning situations, Percebois 2002, 141-154.

7. Cf. Chapelle 1989, 1997, 2001; Salaberry 1999, Hegelheimer 2000.

8. Cf. the work that we are undertaking with Carol Chapelle and Lynn Chue (Chapelle et al. 2003). Our aim is to see whether the fact of combining three analytic approaches (interactionist, systemic and ergonomic) might renew our vision and understanding of CALL learning.

\section{ABSTRACTS}

This paper aims at presenting the contribution of cognitive ergonomics to the research carried out in language centres. After a brief presentation of the self-access room of the language centre which was surveyed, the authors describe the ergonomic concepts: instrumental genesis (Rabardel 1995) and task redefinition (Leplat 1997), which served as a theoretical framework for the empirical studies carried out in the self-access room. Two empirical studies are, then, described to illustrate an ergonomic procedure. The first macroscopic descriptive study points out that specific pattern of behaviours are associated to each medium: the printed paper, the TV set or the personal computer. The second study compares the behaviours of students who received the help of a teacher-tutor to the behaviours of students whose work was not assisted. Results show an interaction between the pedagogical modes and behavioural patterns. In particular, the students whose work was tutored displayed a wider repertoire of behaviours than those whose work was not piloted. In the wake of these quantitative studies, a qualitative 
research program followed. This program, first focused on the learners and then on the teachers, is summed up in the final part of this paper.

Après une brève présentation de la médiathèque du centre de langues qui fut l'objet de la recherche, les auteurs détaillent les concepts ergonomiques : la genèse instrumentale (Rabardel 1995) et la redéfinition de la tâche (Leplat 1997), qui ont servi de cadre théorique aux recherches menées dans la salle en libre accès. Deux recherches empiriques sont alors présentées afin d'illustrer une démarche de type ergonomique. La première étude, descriptive et macroscopique, révèle que des modèles comportementaux spécifiques sont associés à chaque médium : le document imprimé, le poste de télévision, l'ordinateur. La deuxième étude compare les comportements déployés par les étudiants qui recevaient l'aide d'un enseignant-tuteur à ceux déployés par des étudiants qui ne recevaient pas de guidage pédagogique. Les résultats de ces deux études quantitatives ont suscité un programme de recherches qualitatives, d'abord centrées sur l'apprenant puis sur l'enseignant, et qui font l'objet d'un bref exposé dans une dernière partie.

\section{INDEX}

Mots-clés: centre de langues, cognition, comportement, ergonomie, genèse instrumentale, instrument, salle en libre accès

Keywords: behaviour, ergonomics, instrumental genesis, language centre, self-access room

\section{AUTHORS}

\section{FRANÇOISE RABY}

Françoise Raby est maître de conférences à l'IUFM de Grenoble et enseigne également au département des sciences de l'éducation à l'Université Pierre Mendès France de Grenoble. Elle a créé un des premiers centres de langues dans l'enseignement supérieur en France. Elle a effectué plusieurs études de type ergonomique sur les usages des technologies éducatives dans l'apprentissage des langues, allant des didacticiels ou CD rom de langues aux centres de langues en tant que dispositifs innovants. Francoise.Raby@upmf-grenoble.frhttp://www.upmfgrenoble.fr/sciedu/fraby/

\section{JACQUES BAILLE}

Jacques Baillé est professeur en sciences de l'éducation à l'Université de Grenoble. Il a initié le projet d'appliquer l'ergonomie cognitive aux situations éducatives et effectue maintenant une réflexion à propos de la culture technique conçue comme la culture générale de notre temps et les technologies éducatives vues en tant que modernes utopies. Jacques.Baille@upmf-grenoble.fr

\section{PASCAL BRESSOUX}

Pascal Bressoux est professeur en sciences de l'éducation à l'Université de Grenoble. Il a d'abord élaboré des modèles statistiques conçus pour la recherche éducative et développe maintenant sa recherche dans la direction de la construction du jugement scolaire que portent des enseignants de l'école primaire sur leurs élèves. Pascal.Bressoux@upmf-grenoble.fr http://www.upmfgrenoble.fr/sciedu/Bressoux.html 


\section{CAROL CHAPELLE}

Carol A. Chapelle (Ph.D. Université de l'Illinois à Urbana-Champaign) est professeur de linguistique appliquée à l'Université de l'État de l'Iowa, États-Unis. Son livre, Computer applications in second language acquisition: Foundations for teaching, testing and research (Cambridge CUP, 2001) fait l'état des lieux de la recherché en EIAO, et suggère des pistes de recherche dans le domaine des technologies appliquées aux langues secondes. Elle est rédactrice en chef de la revue TESOL Quarterly. http://www.public.iastate.edu/ carolc/ 